Original Russian Text (C) 2020 A.P. Geraskina published in Forest Science Issues Vol. 3, No. 3 , pp. $1-20$

DOI $10.31509 / 2658-607 x-202141 \mathrm{~g} 15$

\title{
IMPACT OF EARTHWORMS OF DIFFERENT MORPHO-ECOLOGICAL GROUPS ON CARBON ACCUMULATION IN FOREST SOILS
}

\author{
A.P. Geraskina \\ Center for Forest Ecology and Productivity of the Russian Academy of Sciences \\ Profsoyuznaya st. 84/32 bldg. 14, Moscow 117997, Russian Federation \\ *Email: angersgma@gmail.com \\ Received 25.05.2020 \\ Accepted 24.06. 2020
}

To date, forest ecology has not made any clear conclusions regarding the impact of large saprophagous invertebrates such as earthworms on soil carbon dynamics. Some authors claim that earthworm activities result in decreased carbon accumulation. Other studies show that earthworms contribute to soil carbon accumulation. At the same time, many studies do not take into account the differences between trophic and digging activity of different morpho-ecological groups of earthworms in different soil horizons. The objective of this study was to carry out differentiated assessment of the impact of different morpho-ecological groups of earthworms on carbon accumulation and correspondent soil parameters (nitrogen content and $\mathrm{C} / \mathrm{N}$ ratio) throughout the change in forest succession status. Field operations were performed in the spring and summer of 2016 and 2018 in three regions: Bryansk Oblast (Bryansk Forest reserve), Moscow Oblast (Moskva-Oka plain, Valuyevsky urban forest) and Northwest Caucasus (Krasnodar Krai, Apsheron forestry; Republic of Adygeya, Caucasian Biosphere Reserve). Three main stages of coniferousbroadleaf forest restoration after clear cuttings were identified in each region. Three test plots 50x50 $\mathrm{m}$ were allocated for each stage; geobotanical and soil descriptions as well as earthworm registration were carried out on each plot. It was found out that during the change in forest succession status the species composition and the set of morpho-ecological groups of earthworms became more complicated, but there was no successive replacement of any groups with others. Ambiguous effects of different morpho-ecological groups of earthworms on carbon accumulation in forest soils were revealed. Negative correlation was found between the total biomass of earthworms feeding on the soil surface (epigeic, epi-endogeic and anecic species) and litter store. In the humus horizon, the biomass of epi-endogeic species was positively correlated with the content of carbon. $\mathrm{C} / \mathrm{N}$ ratio and nitrogen content are unidirectionally correlated with the biomass of earthworms in the horizons of their activity: with an increase in the biomass of earthworms of different morphoecological groups, the $\mathrm{C} / \mathrm{N}$ ratio decreases, and the nitrogen content increases.

Key words: forest type, succession status, chronoseries, litter, nitrogen, $C / N$ ratio, saprophagous invertebrates, biomass

Productivity of forest ecosystems is largely determined by the activity of soil saprophages, since the bulk of energy flows through the detrital food chain (Striganova, 2012). The flow intensity of dead organic matter entering the soil is at least $95 \%$ of the total amount of organic matter assimilated by producers (Begon et al., 1986). In the mixed and broadleaf forests of the European part of Russia, the main agents contributing to plant litter decomposition are large saprophages, up to $90 \%$ of their biomass consisting of earthworms (Abaturov, 1976; Striganova, 1980). 
On the one hand, plant litter (composed of leaves, stems, and roots) and plant root secretions serve as a source of carbon for earthworms (Goncharov, 2014; Gleixner, 2013). On the other hand, earthworms provide carbon fixation in the soil in two main ways: by means of humus formation as a result of their trophic activity and by means of carbon transfer from the soil surface to lower horizons during their active burrowing. In the absence of earthworms and other large saprophages, the destruction of plant litter is carried out by microorganisms and saprotrophic meso- and microfauna not capable of transferring carbon to the mineral horizons of soils. Moreover, during the microbial respiration, carbon dioxide is released, which leads to carbon loss rather than its fixation in the soil (Frouz et al., 2013).

Recent studies of global carbon dynamics in terrestrial ecosystems provide ambiguous estimates of the impact of earthworms on carbon accumulation in the soil. Some authors claim that earthworm activity results in reduced carbon accumulation (Alban, Berry, 1994; Burtelow et al., 1998; Bohlen et al., 2004). Other studies show that earthworms contribute to soil carbon accumulation (Pulleman et al., 2005; Novara et al., 2015). Probably, these conflicting conclusions are attributed to the fact that most studies consider the complex of earthworms as a whole, taking into account the total biomass of all earthworm species. This does not factor in any differences between individual morpho-ecological groups of earthworms, where in relation to the organic matter of the soil, primary humus-forming species are distinguished, i.e. species feeding on the surface (epigeic, epi-endogeic and anecic), as well as secondary humus-forming species feeding in the soil (endogeic) (Perel', 1979).

The objective of this study was to make a differentiated assessment of the impact of earthworms of different morpho-ecological groups on carbon accumulation in forest soils during the change in forest succession status.

Tasks: 1. To study the species composition, biomass and dynamics of morpho-ecological groups of earthworms during the transformation of forest communities.

2. To analyze the impact of earthworms of 4 morpho-ecological groups on litter stores and carbon content in soil horizons.

3. To evaluate the impact of earthworms of different morpho-ecological groups on the $\mathrm{C} / \mathrm{N}$ ratio and nitrogen content as the most significant soil indicators associated with carbon accumulation processes that are regulated by earthworms.

\section{MATERIALS AND METHODS}

Field work was carried out in the spring and summer of 2016 and 2018 in coniferousbroadleaf forests of three regions of the European part of Russia: Bryansk Woodlands (territory of the Bryansk Forest reserve $52.5464 \mathrm{~N}, 34.0797 \mathrm{E}$ ), Moskva-Oka plain (Valuyevsky urban forest - $55.5780 \mathrm{~N}$, 37.3272 E), and the Northwest Caucasus (Apsheron forestry, Otdalenny village, Krasnodar Krai - 44.0669 N, 39.7164 E, and the Guzeripl cordon of the Caucasian biosphere reserve, Republic of Adygeya $44.0002 \mathrm{~N}, 40.1421 \mathrm{E}$ ). Three types of forest, which represent different stages of the succession change of plant communities (chronoseries) after clear cuttings, have been examined in each region (Lukina et al., 2018).

In Bryansk Forest reserve, the following forests were studied: pine forests (aged 40-60 years), pine-broadleaf forests (aged 70-120 years), and broadleaf-spruce forests (older than 120 years). Soil type: sod-podzolic ferrous illuvial sandy soils on fluvioglacial sands (Klassifikacija pochv..., 2004), or Podzols Albic (WRB, 2015). The clay-silt fraction in the soil-forming rocks ranges from 0.5 to $5 \%$. Active acidity of the soil-forming rocks: pH 5.1-5.7 (Lukina et al., 2018).

On the territory of the Moskva-Oka plain, the following forests were studied: birchlinden forests with aspen (aged 50-70 years), linden forests with birch and aspen (aged 90110 years), and broadleaf-spruce forests (aged 115-125 years). The soil is sod-podzolic middle loamy on covering loam with underlying moraine (Klassifikacija pochv..., 2004), or Retisols Albic (WRB, 2015). The clay-silt fraction in the soil-forming rocks ranges from 34.3 to $45.3 \%$. Active acidity of 
the soil-forming rocks: $\mathrm{pH}$ 5.1-5.6 (Lukina et al., 2018).

On the territory of the Northwest Caucasus, the following forests were studied: aspen-hornbeam forests (aged 45-65 years), fir-beech-hornbeam forests (aged 80-110 years), fir-beech forests (older than 400 years). Soil type: heavy loamy brown soil on clay shales (Klassifikacija pochv..., 2004), or Cambisols Dystric (WRB, 2015). The claysilt fraction in the soil-forming rocks ranges from 36.5 to $72.7 \%$. Active acidity of the soilforming rocks: $\mathrm{pH}$ 5.5-5.7 (Lukina et al., 2018).

Three trial plots (TPs) of 50x50 m (27 in total), where geobotanical, soil descriptions and earthworm registration were performed, were selected for each type of forest in three regions (Geras'kina, 2018; Lukina et al., 2018; Kuznecova et al., 2019; Shevchenko et al., 2019).

Earthworms were registered by excavation of soil with hand sorting of samples: at each TP, from 10 (Bryansk Woodlands, MoskvaOka plain) to 16 samples (Northwest Caucasus) with an area of $25 \times 25 \mathrm{~cm}^{2}$ and a depth of $30 \mathrm{~cm}$ were taken. In total, 90 soil samples were taken in the forests of the Bryansk Forest reserve, 60 - in the forests of the Moskva-Oka plain, and 144 - in the forests of the Northwest Caucasus. Earthworms were fixed in $96 \%$ ethyl alcohol. Species were identified using the key-book by T.S. Vsevolodova-Perel' (1997). Morphoecological groups of earthworms were classified according to T.S. Perel' (1979). The biomass was determined by weighing fixed earthworms with a full intestine.

At each TP, reference soil pits were made under the forest canopy, from which litter (L subhorizon) and soil (every $10 \mathrm{~cm}$ ) were sampled down to the soil-forming rock. In all samples, $\mathrm{pH}$ of the water extract was measured using potentiometric analysis. The carbon and nitrogen content was evaluated in the ecoanalytic laboratory of the Chromatography Research Equipment Sharing Centre of the Komi Biology Institute, Scientific Centre of the Ural Branch of the Russian Academy of Sciences, using a $\mathrm{CHN}$ analyzer EA 1110 (CHNS-O). Litter samples of $0.25 \times 0.25 \mathrm{~m}$ were taken at each TP in three replications to determine the mass of the litter and its carbon reserves. Carbon stocks in the litter and soil mineral horizons were calculated according to the procedural guidelines (Metodicheskie ukazanija..., 2017). Calculations were carried out taking into account the actual thickness of horizons as well as for fixed layers of $0-30,0-50$, and 0 $100 \mathrm{~cm}$ (Lukina et al., 2018; Kuznecova et al., 2019). Soil horizons: litter or organogenic horizon (O), humus or humus-accumulative horizon (A), eluvial horizon (E), illuvial horizon (B), parent rock (C) were classified according to the National Atlas of Soils of the Russian Federation (2011).

Statistical processing of data on earthworms was performed using the MS Excel 2019 and Statistica 6.0 software packages. To detect statistically significant differences, the nonparametric Kruskal-Wallis test was used, the significance level (p) was set equal to $\leq 0.05$. Since the values of the biomass of earthworms of different morphoecological groups varied greatly, further analysis of their correlation with carbon accumulation in different soil horizons (and the associated indicators, i.e. content of $\mathrm{N}$ and the $\mathrm{C} / \mathrm{N}$ ratio) included only the morphoecological groups of earthworms, where the variation of biomass in the samples showed normal distribution. Based on the values of the Pearson's test $(\mathrm{K}$ obs. $<\mathrm{K}$ crit.; $\mathrm{K}$ crit. $=$ 12.591), normal distribution was shown by the data sets of biomass of epigeic earthworms in the forests of the Bryansk Woodlands and the Moskva-Oka plain, epiendogeic earthworms - in the forests of the Moskva-Oka plain, endogeic earthworms - in the forests of the Northwest Caucasus and the Moskva-Oka plain, as well as the total biomass of earthworms of morpho-ecological groups feeding on the soil surface (epigeic, epi-endogeic and anecic) in the forests of the Northwest Caucasus and the Moskva-Oka plain. These data series were used for linear regression analysis (coefficient of determination $\mathrm{R}^{2}$ ) in order to identify correlations between groups of earthworms and soil parameters. Activity horizons of different morpho-ecological groups of earthworms that are significantly influenced by earthworms were taken into account. 
Epigeic, epi-endogeic and anecic species are active in the litter horizon, and epi-endogeic and endogeic species are active in the humus horizon.

\section{RESULTS AND DISCUSSION}

1. Species diversity and changes in the composition of morpho-ecological groups of earthworms during post-cutting forest successions

\subsection{Forests of the «Bryansk Forest»} reserve

4 species of earthworms of two morphoecological groups were found: epigeic Dendrodrilus rubidus tenuis (Eisen, 1874), Dendrobaena octaedra (Savigny, 1826); epi- endogeic Lumbricus rubellus Hoffmeister, 1843, and Eisenia nordenskioldi (Eisen, 1879) (Table 1). In total, at least ten common species were found in the zone of coniferousbroadleaf forests (Perel', 1979). Poor species composition in the studied forests is primarily due to the light granulometric composition of the soils of this territory - in all three types of forest, the soils are sandy loam (Lukina et al., 2018; Kuznecova et al., 2019). Light sandy loam soils with weak moisture-retention capacity are known to be an unfavorable habitat for earthworms (Zhukov, 2004; Curry, 2004 , etc.).

Table 1. Species composition and numbers of earthworms of different morpho-ecological groups found in coniferous-broadleaf forests of the studied regions

\begin{tabular}{|c|c|c|c|c|}
\hline \begin{tabular}{|c}
$\begin{array}{c}\text { Morpho-ecological } \\
\text { group }\end{array}$ \\
\end{tabular} & Region & Forest type & Species & Number, ind. $/ \mathrm{m}^{2} \pm \mathrm{SE}$ \\
\hline \multirow{21}{*}{$\begin{array}{c}\text { Epigeic } \\
\text { (4 species) }\end{array}$} & \multirow{6}{*}{$\begin{array}{c}\text { Bryansk } \\
\text { Woodlands }\end{array}$} & $\mathrm{B} 1$ & - & - \\
\hline & & \multirow[t]{2}{*}{ B2 } & D. octaedra & $12.0 \pm 4.6$ \\
\hline & & & D. r. tenuis & $2.0 \pm 0.3$ \\
\hline & & \multirow[t]{3}{*}{ B3 } & D. octaedra & $7.3 \pm 2.8$ \\
\hline & & & D. r. tenuis & $0.7 \pm 0.3$ \\
\hline & & & Total: 2 species & \\
\hline & \multirow{7}{*}{$\begin{array}{l}\text { Moskva-Oka } \\
\text { plain }\end{array}$} & M1 & - & - \\
\hline & & \multirow[t]{2}{*}{ M2 } & D. octaedra & $8.8 \pm 0.8$ \\
\hline & & & L. castaneus & $0.8 \pm 0.1$ \\
\hline & & \multirow{4}{*}{ M3 } & D. octaedra & $6.4 \pm 1.3$ \\
\hline & & & D. r. tenuis & $2.0 \pm 0.5$ \\
\hline & & & L. castaneus & $0.9 \pm 0.2$ \\
\hline & & & Total: 3 species & \\
\hline & \multirow{8}{*}{$\begin{array}{l}\text { Northwest } \\
\text { Caucasus }\end{array}$} & \multirow[t]{2}{*}{$\mathrm{C} 1$} & D. octaedra & $1.3 \pm 0.2$ \\
\hline & & & D. attemsi & $0.3 \pm 0.1$ \\
\hline & & \multirow[t]{2}{*}{$\mathrm{C} 2$} & D. octaedra & $7.0 \pm 1.6$ \\
\hline & & & D. attemsi & $0.7 \pm 0.3$ \\
\hline & & \multirow[t]{4}{*}{$\mathrm{C} 3$} & D. octaedra & $1.7 \pm 0.3$ \\
\hline & & & D. attemsi & $0.3 \pm 0.1$ \\
\hline & & & D. r. tenuis & $0.3 \pm 0.1$ \\
\hline & & & Total: 3 species & \\
\hline \multirow{13}{*}{$\begin{array}{l}\text { Epi-endogeic } \\
\text { (3 species) }\end{array}$} & \multirow{4}{*}{$\begin{array}{c}\text { Bryansk } \\
\text { Woodlands }\end{array}$} & $\mathrm{B} 1$ & - & - \\
\hline & & $\mathrm{B} 2$ & E. nordenskioldi & $0.3 \pm 0.2$ \\
\hline & & B3 & L. rubellus & $1.3 \pm 0.4$ \\
\hline & & & Total: 2 species & \\
\hline & \multirow{4}{*}{$\begin{array}{l}\text { Moskva-Oka } \\
\text { plain }\end{array}$} & M1 & L. rubellus & $14.0 \pm 4.5$ \\
\hline & & M2 & L. rubellus & $16.0 \pm 4.5$ \\
\hline & & M3 & L. rubellus & $42.0 \pm 7.6$ \\
\hline & & & Total: 1 species & \\
\hline & \multirow{4}{*}{$\begin{array}{l}\text { Northwest } \\
\text { Caucasus }\end{array}$} & $\mathrm{C} 1$ & E. fetida & $0.5 \pm 0.06$ \\
\hline & & $\mathrm{C} 2$ & - & - \\
\hline & & C3 & E. fetida & $0.5 \pm 0.1$ \\
\hline & & & Total: 1 species & \\
\hline & & B1 & - & - \\
\hline
\end{tabular}




\begin{tabular}{|c|c|c|c|c|}
\hline \multirow{18}{*}{$\begin{array}{l}\text { Endogeic } \\
(6 \text { species })\end{array}$} & \multirow{2}{*}{$\begin{array}{c}\text { Bryansk } \\
\text { Woodlands }\end{array}$} & B2 & - & - \\
\hline & & B3 & - & - \\
\hline & \multirow{8}{*}{$\begin{array}{l}\text { Moskva-Oka } \\
\text { plain }\end{array}$} & \multirow[t]{3}{*}{ M1 } & A. c. caliginosa & $29.0 \pm 4.7$ \\
\hline & & & A. rosea & $32.0 \pm 5.6$ \\
\hline & & & O. lacteum & $4.0 \pm 0.5$ \\
\hline & & \multirow[t]{2}{*}{ M2 } & A. c. caliginosa & $39.2 \pm 7.1$ \\
\hline & & & A. rosea & $16.0 \pm 3.9$ \\
\hline & & \multirow[t]{2}{*}{ M3 } & A. c. caliginosa & $8.0 \pm 2.4$ \\
\hline & & & A. rosea & $4.8 \pm 0.9$ \\
\hline & & & Total: 3 species & \\
\hline & \multirow{8}{*}{$\begin{array}{l}\text { Northwest } \\
\text { Caucasus }\end{array}$} & \multirow[t]{3}{*}{$\mathrm{C} 1$} & A. jassyensis & $11.3 \pm 3.0$ \\
\hline & & & D. s. schmidti & $17.7 \pm 2.9$ \\
\hline & & & D. tellermanica & $5.7 \pm 1.5$ \\
\hline & & \multirow[t]{2}{*}{$\mathrm{C} 2$} & A. jassyensis & $6.3 \pm 3.5$ \\
\hline & & & D. s. schmidti & $22.0 \pm 4.8$ \\
\hline & & \multirow[t]{2}{*}{$\mathrm{C} 3$} & A. jassyensis & $8.0 \pm 1.0$ \\
\hline & & & D. s. schmidti & $24.6 \pm 8.6$ \\
\hline & & & Total: 3 species & \\
\hline \multirow{13}{*}{$\begin{array}{c}\text { Anecic } \\
(3 \text { species })\end{array}$} & \multirow{3}{*}{$\begin{array}{c}\text { Bryansk } \\
\text { Woodlands }\end{array}$} & B1 & - & - \\
\hline & & $\mathrm{B} 2$ & - & - \\
\hline & & B3 & - & - \\
\hline & \multirow{6}{*}{$\begin{array}{c}\text { Moskva-Oka } \\
\text { plain }\end{array}$} & M1 & - & - \\
\hline & & \multirow[t]{2}{*}{ M2 } & A. longa & $3.2 \pm 0.2$ \\
\hline & & & L. terrestris & $1.6 \pm 0.1$ \\
\hline & & \multirow[t]{3}{*}{ M3 } & A. longa & $1.6 \pm 0.4$ \\
\hline & & & L. terrestris & $0.8 \pm 0.3$ \\
\hline & & & Total: 2 species & \\
\hline & \multirow{4}{*}{$\begin{array}{l}\text { Northwest } \\
\text { Caucasus }\end{array}$} & $\mathrm{C} 1$ & D. mariupolienis & $0.5 \pm 0.3$ \\
\hline & & $\mathrm{C} 2$ & D. mariupolienis & $2.0 \pm 0.2$ \\
\hline & & $\mathrm{C} 3$ & D. mariupolienis & $6.7 \pm 3.3$ \\
\hline & & & Total: 1 species & \\
\hline
\end{tabular}

Explanatory notes:

B1: pine forests; B2: pine-broadleaf forests; B3: broadleaf-spruce forests;

M1: birch-linden forests with aspen; M2: linden forests with birch and aspen; M3: spruce-broadleaf forests;

C1: aspen-hornbeam forests; C2: fir-beech-hornbeam forests; C3: fir-beech forests

In pine forests (B1), no earthworms were found in soil samples. Moreover, no earthworms were found in these forests during the observation of favorable habitats either, i.e. degradations, pits, deadwood of late stages of decomposition. The absence of earthworms in these forests is not only due to the light granulometric composition of the soil, but also due to the litter quality. The litter is dominated by difficultly decomposed fractions (pine) and ground cover (bilberry, cowberry, heather). Litter acidity ranges from 4.3 to 4.7 , which is also unfavorable for earthworms. The optimal $\mathrm{pH}$ for the active life, including reproduction, of most earthworm species ranges from 5.5 to values close to neutral (Perel', 1979; Hirth et al., 2009; Moore et al., 2013). In pine-broadleaf forests (B2), three earthworm species were found: epigeic D. octaedra and D. r. tenuis as well as epi-endogeic E. nordenskioldi. The number and biomass of earthworms are low (Table 1, Fig. 1), but their life in these forests, in contrast to pine forests, is possible due to the presence of high-quality litter provided by undergrowth (linden, maple) and shrubs (buckthorn, hazel). Also, the litter in these forests is more favorable for earthworms due to increased $\mathrm{pH}$ values up to 5.5-5.9, as compared to the previous stage of succession.

In broadleaf-spruce forests (B3), three species of Lumbricidae were found: epigeic D. octaedra, D. r. tenuis, and epiendogeic L. rubellus. The number and biomass of earthworms, as in complex pine forests, is low (Table 1, Fig. 1), despite the increased proportion of high-quality litter provided by the tree layer (linden, maple, ash), 
undergrowth (linden, maple, elm), and shrubs (hazel, bird cherry). Litter acidity in these forests is within optimal values: $\mathrm{pH}$ is 5.9
6.4, which is not a limiting factor for earthworm activity.

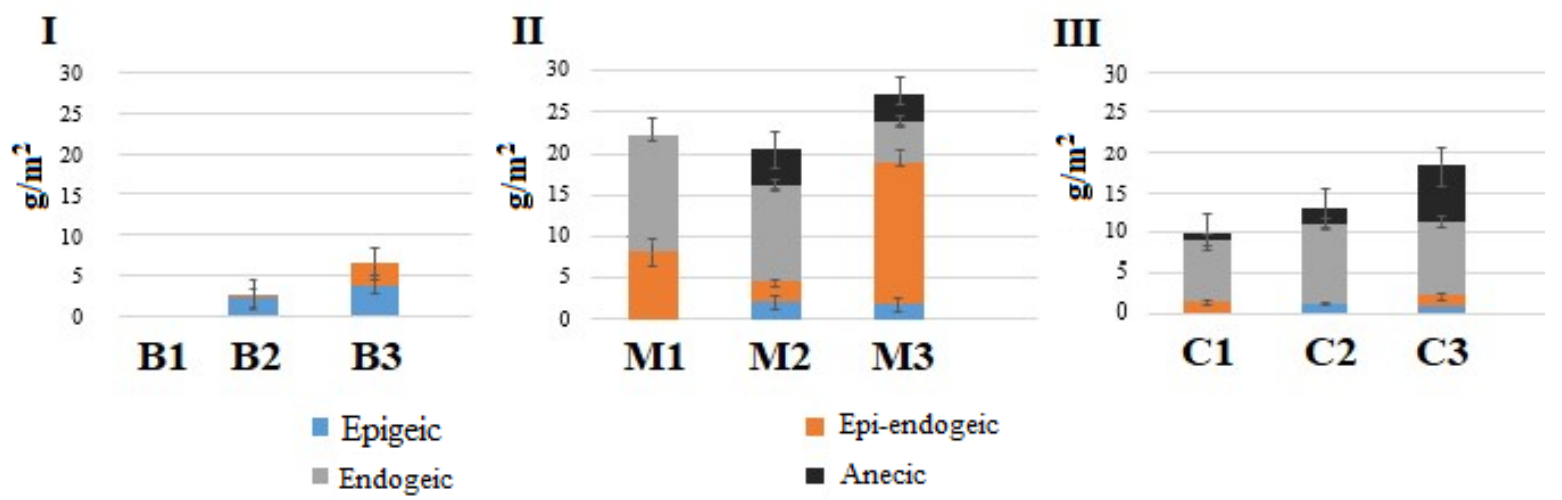

Figure 1. Dynamics of the biomass of morpho-ecological groups of earthworms during changes in the succession status of forests

Note. I - Bryansk Woodlands, II - Moskva-Oka plain, III - Northwest Caucasus. For designation of forest types B1...C3 see Table 1.

Statistically significant differences in the biomass of epigeic and epi-endogeic earthworm species were found between pinebroadleaf forests (B2) and broadleaf-spruce forests (B3), and there were also differences in the total biomass of earthworms at three stages of succession (Fig. 1, Table 2).

Table 2. Values of the Kruskal-Wallis H-test when comparing the biomass of earthworms of different morpho-ecological groups in different forest types

\begin{tabular}{|c|c|c|c|c|}
\hline $\begin{array}{l}\text { Morpho-ecological } \\
\text { group }\end{array}$ & Compared forest types & $\mathrm{df}$ & $\mathrm{Hu}$ & $P$ \\
\hline \multirow[t]{3}{*}{ Epigeic } & $* \mathrm{~B} 2 \times \mathrm{B} 3$ & 1 & 2.167 & $0.041 * *$ \\
\hline & M2 x M3 & 1 & 0.079 & 0.777 \\
\hline & $\mathrm{C} 1 \times \mathrm{C} 2 \times \mathrm{C} 3$ & 2 & 0.492 & 0.781 \\
\hline \multirow[t]{3}{*}{ Epi-endogeic } & $\mathrm{B} 2 \times \mathrm{B} 3$ & 1 & 1.750 & $0.048 * *$ \\
\hline & $\mathrm{M} 2 \times \mathrm{M} 2 \times \mathrm{M} 3$ & 2 & 4.610 & $0.036^{* *}$ \\
\hline & $\mathrm{C} 1 \times \mathrm{C} 3$ & 1 & 0.437 & 0.508 \\
\hline \multirow[t]{2}{*}{ Endogeic } & $\mathrm{M} 2 \times \mathrm{M} 2 \times \mathrm{M} 3$ & 2 & 8.564 & $0.014 * *$ \\
\hline & $\mathrm{C} 1 \times \mathrm{C} 2 \times \mathrm{C} 3$ & 2 & 0.862 & 0.649 \\
\hline \multirow[t]{2}{*}{ Anecic } & M2 x M3 & 1 & 0.784 & 0.375 \\
\hline & $\mathrm{C} 2 \times \mathrm{C} 3$ & 1 & 4.419 & $0.012 * *$ \\
\hline \multirow[t]{3}{*}{ All groups } & $\mathrm{B} 1 \times \mathrm{B} 2 \times \mathrm{B} 3$ & 2 & 6.882 & $0.032 * *$ \\
\hline & $\mathrm{M} 2 \times \mathrm{M} 2 \times \mathrm{M} 3$ & 2 & 0.929 & 0.629 \\
\hline & $\mathrm{C} 1 \times \mathrm{C} 2 \times \mathrm{C} 3$ & 2 & 0.965 & 0.617 \\
\hline
\end{tabular}

Note: *For designation of forest types B1...C3, see Table 1.

** The differences are statistically significant $(\mathrm{p} \leq 0.05)$.

Thus, with changing plant communities and the litter quality becoming more favorable for earthworms, epigeic and epiendogeic species show themselves in the soils of light granulometric composition of the Bryansk Woodlands. Nevertheless, the number of earthworms remains numerically insignificant, and they do not play any significant functional role in litter decomposition (Lukina et al., 2018).

\subsection{Forests of the Moskva-Oka plain}

9 species of earthworms belonging to 4 morpho-ecological groups were found: epigeic D. r. tenuis, D. octaedra, Lumbricus 
castaneus (Savigny, 1826); epi-endogeic $L$. rubellus, endogeic Aporrectodea caliginosa caliginosa (Savigny, 1826), Aporrectodea rosea (Savigny, 1826), Octolasium lacteum (Oerley, 1885), and anecic Lumbricus terrestris Linnaeus, 1758, Aporrectodea longa (Ude, 1885). Factors favorable for earthworm vital activity in these forests are the granulometric composition of soils (middle loamy), the presence of high-quality litter from trees and shrubs, as well as the optimal litter acidity (5.8-6.1) at all stages of succession.

In birch-linden forests with aspen (M1), 4 species of earthworms were found: the epiendogeic L. rubellus as well as endogeic $A$. $c$. caliginosa, A. rosea, O. lacteum. Endogeic species make the largest contribution to the biomass (Fig. 1). The absence of epigeic species is probably due to the rapid utilization of high-quality litter of linden and birch by soil biota (Berezina, 2016).

In linden forests with birch and aspen (M2), 7 species of earthworms were identified: epigeic D. octaedra, L. castaneus, epi-endogeic L. rubellus, endogeic $A$. $c$. caliginosa, A. rosea, and anecic L. terrestris, A. longa (Table 1). Despite the presence of 4 morpho-ecological groups of Lumbricidae, the biomass of endogeic species exceeds the biomass of other groups (Fig. 1).

In broadleaf spruce forests (M3), 8 species of earthworms were identified: epigeic $D$. octaedra, D. $\quad r$. tenuis, L. castaneus, epiendogeic L. rubellus, endogeic A. caliginosa, $A$. rosea, and anecic $L$. terrestris, $A$. longa. The difference between the spruce-broadleaf forest and the two previous stages of the chronoseries is a significant decrease in the biomass of endogeic species and the 4.5-fold increase in the biomass of the epi-endogeic $L$. rubellus.

Thus, in the middle loamy soils of the Moskva-Oka plain, the completed complex of earthworms is only found in the oldest forests (older than 110 years). Despite the presence of rapidly decomposing broadleaf litter (from linden, birch), only two morpho-ecological groups of earthworms are active in these forests at the initial stages of succession, i.e. endogeic and epi-endogeic. With increasing age of forest communities and increasing proportion of slowly decomposing litter (spruce) in the litter horizon, the conditions for epigeic, epi-endogeic and anecic species that feed on leaf litter of trees, shrubs and herbs on the soil surface remain favorable (Perel', 1979; Hoeffner et al., 2018; Huang et al., 2020).

\subsection{Forests of the Northwest Caucasus}

8 species of earthworms belonging to 4 morpho-ecological groups were found: epigeic D. r. tenuis, D. octaedra, Dendrobaena attemsi Michaelsen, 1902; epiendogeic Eisenia fetida (Savigny, 1826), endogeic Dendrobaena schmidti schmidti (Michaelsen, 1907), Dendrobaena tellermanica Perel', 1966, Aporrectodea jassyensis (Michaelsen, 1891), and anecic Dendrobaena mariupolienis Wyssotzky, 1898.

7 species of earthworms were found in aspen-hornbeam forests (C1): epigeic $D$. octaedra, D. attemsi; epi-endogeic E. fetida; endogeic $D$. s. schmidti, $D$. tellermanica, $A$. jassyensis, and anecic D. mariupolienis (Table 1). The biomass of endogeic species is significantly higher than that of other groups (Fig. 1).

5 species of earthworms were found in firbeech-hornbeam forests (C2): epigeic $D$. octaedra, D. attemsi; endogeic D. s. schmidti, A. jassyensis, and anecic D. mariupolienis.

In the oldest fir-beech forests (C3), that are older than 400 years, 7 species of earthworms were identified: epigeic $D$. octaedra, $D$. attemsi, D. r. tenuis; epi-endogeic E. fetida; endogeic D. s. schmidti, A. jassyensis, and anecic $D$. mariupolienis. An important feature of the earthworm population at the terminal stage of succession of coniferous-broadleaf forests of the Northwest Caucasus is a 4-9fold increase in the biomass of anecic earthworms as compared to the previous stages of the chronological order (Geraskina, 2018), the differences are statistically significant (Fig. 1, Table 2).

In general, 4 morpho-ecological groups of earthworms were present in the chronoseries of the forests of the Northwest Caucasus already at the initial stages, which is due to favorable forest brown soils and the presence of mixed litter, which is better for earthworms in trophic and topical terms (Sariyildiz, 2008; Sariyildiz, Küçük, 2008). Litter acidity at all 
stages of succession is close to optimal values ( $\mathrm{pH}$ 5.1-6.0) and does not limit the activity of earthworms. As in the forests of the MoskvaOka plain, increasing biomass of anecic earthworms was observed in the Northwest Caucasus in the process of succession.

Thus, the example of three types of forest study objects in different regions showed that the set of morpho-ecological groups of earthworms is determined by the soil granulometric composition and litter quality of the tree layer, undergrowth and shrubs. At the initial stages of post-cutting forest restoration, the composition of morphoecological groups of earthworms is incomplete (with the exception of the forests of the Northwest Caucasus). With changing succession status of forests, the set of morpho-ecological groups of earthworms becomes more complex, but there is no successive replacement of one group by others.

2. Impact of earthworms of different morpho-ecological groups on carbon accumulation in forest soils and associated soil parameters, such as litter store, nitrogen content, and $\mathrm{C} / \mathrm{N}$ ratio

Litter thickness relies on the activity of earthworms (Vsevolodova-Perel' et al., 1995; Suarez et al., 2006; Holdsworth et al., 2012; Huang et al., 2020, etc.). Correlation analysis showed that in all regions, the stock of the $\mathrm{L}$ subhorizon is negatively related to the biomass of earthworms active in the litter horizon. The highest values of the coefficient of determination $\left(\mathrm{R}^{2}=0.65\right)$ were obtained for the forests of the Bryansk Woodlands, where the store of $\mathrm{L}$ subhorizon is at least twice as high as compared to the forests of the Moskva-Oka plain and the Northwest Caucasus (with the exception of plots of oldaged fir-beech forests) (Fig. 2). Litter accumulation in the forests of the Bryansk Woodlands corresponds to a very low biomass of earthworms (Fig. 1). As our studies have shown, the biomass of other groups of saprophagous invertebrates is also small here. Litter store in the forests of the
Moskva-Oka plain is probably more actively controlled by the activity of the epi-endogeic L. rubellus, since its contribution to the total biomass of earthworms is significantly higher in forest communities than the contribution of epigeic and anecic species (Fig. 1).

In the forests of the Northwest Caucasus, among the groups of earthworms that regulate litter stores, anecic species make the greatest contribution due to their significantly higher biomass than that of epigeic and epi-endogeic species (Fig. 1).

A significant negative correlation was found between the biomass of epi-endogeic earthworms and the $\mathrm{C} / \mathrm{N}$ ratio in the litter and in the humus horizon (the example of the forests of the Moskva-Oka plain, where the highest biomass of L. rubellus was found (Fig. 3a, 4a)). And on the contrary, the biomass of epi-endogeic L. rubellus is positively related to the nitrogen content in the litter and the humus horizon (Fig. 3b, 4b). At the same time, the direction of correlation with the organic carbon content differs: a negative correlation of carbon content with the biomass of epi-endogeic earthworms is shown in the litter L subhorizon (Fig. 3c), whereas in the humus horizon, on the contrary, there is a positive correlation (Fig. $4 c)$. Since epi-endogeic earthworms actively feed on the soil surface, which can lead to a decrease in the organic carbon content in the litter, but at the same time they belong to the primary humus-forming agents (Perel', 1979), it is most likely that the effect of organic matter accumulation during humus formation is more pronounced in the humus horizon. In addition, as a result of motor activity, organic carbon is transferred from the litter horizon to the humus horizon.

Significant correlations of the biomass of endogeic species were found only with the $\mathrm{C} / \mathrm{N}$ ratio in $\mathrm{A}$ horizon (Fig. 5), where earthworms of this group are most active provided the humidity is sufficient. No significant correlations of endogeic species with nitrogen and carbon content were established. 


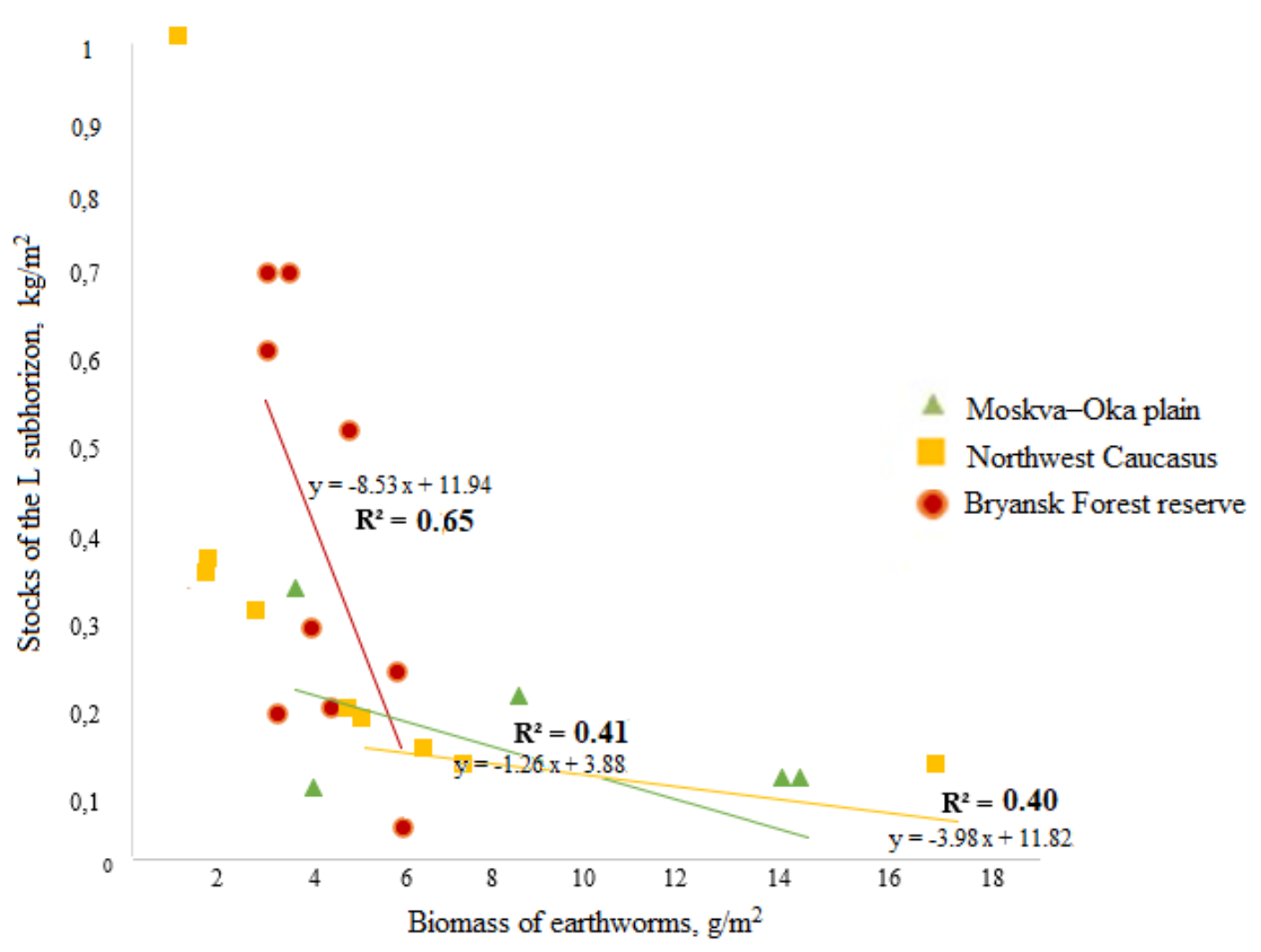

Figure 2. Dependence of the stock of litter L subhorizon on the biomass of epigeic, epi-endogeic and anecic earthworm species

The lack of mineral forms of nitrogen is one of the crucial limiting factors of plant mineral nutrition, since up to $90 \%$ of this element in soils is in the form inaccessible to plants (Mengel, 1996). The activity of earthworms is known to result in soil enrichment with nitrogen forms available for plants. Earthworm coprolites are rich with urea and ammonium ions. Digestive enzymes of earthworms boost the activity of nitrifying and ammonifying bacteria thus reducing the loss of free nitrogen, which is fixed in the form of compounds, ammonium nitrogen going into nitrites and nitrates (Kozlovskaja, 1976). Experiments with E. nordenskioldi, which live in dark gray soil under broadleaf forests, have shown that the soil is enriched with active forms of amino nitrogen available for absorption by plant roots, as well as with free and bound amino acids (Kozlovskaja et al., 1983; Striganova et al., 1989). In experiments with epi-endogeic and endogeic earthworms it was shown that ammonium contained in earthworm coprolites is able to modify soil nitrification, causing long-term cumulative effects that are vastly superior to their direct effect (Bitjuckij et al., 2007). In experiments with anecic earthworms, it was shown that the available nitrogen content in the soil increased by $0.03 \mathrm{mg} / \mathrm{kg}$ for every 0.1 $\mathrm{g}$ of earthworm biomass (Andriuzzi et al., 2016). In natural ecosystems, the flow of soil nitrogen through earthworm populations amounts to dozens of kilograms per hectare per year (Lee, 1985; Parmelee and Crossley, 1988). Also, the soil is enriched with nitrogen through the death of earthworms: their annual mortality rate is on average $60 \%$ of the total population (Lavelle et al., 1998). In the soils of Central Europe, the nitrogen yield reaches $24 \mathrm{~g} / \mathrm{m}^{2}$ after the death of earthworms, which is comparable to the annual dose of mineral nitrogen fertilizers (100-200 kg of $\mathrm{N}$ per 1 ha). Earthworm biomass containing 65-75\% of protein decomposes quickly in the soil, but nitrogen bound by microorganisms is washed out more slowly (Lee, 1985; Makeschin, 1997; et al.). 

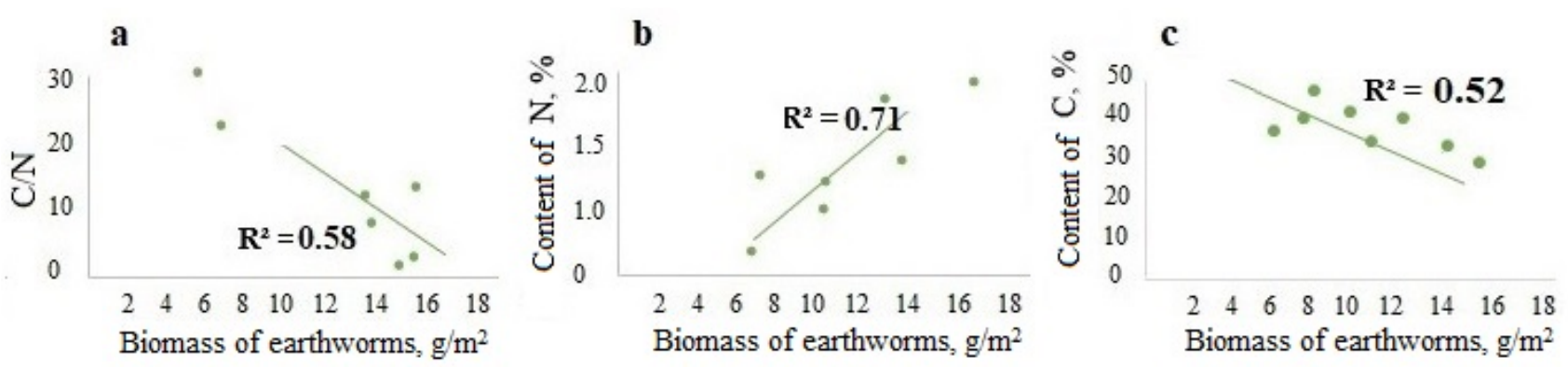

Figure 3. Dependence of the $\mathrm{C} / \mathrm{N}$ ratio (a), nitrogen content (b) and carbon content (c) in the $\mathbf{L}$ subhorizon of litter on the biomass of epi-endogeic earthworms in the forests of the MoskvaOka plain
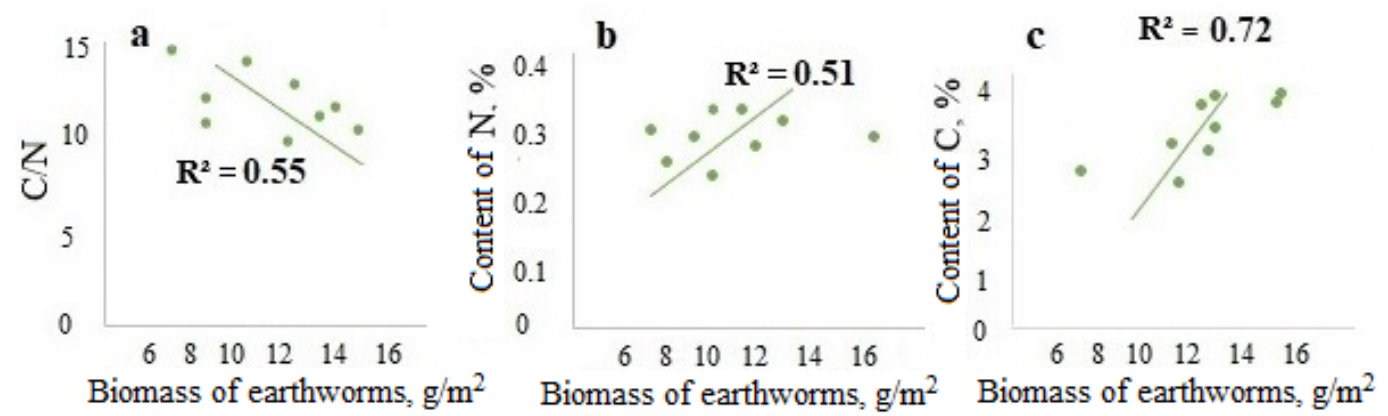

Figure 4. Dependence of the $\mathrm{C} / \mathrm{N}$ ratio (a), nitrogen content (b) and carbon content (c) in A horizon on the biomass of epi-endogeic earthworms in the forests of the Moskva-Oka plain

Earthworms contribute to a significant decrease in the $\mathrm{C} / \mathrm{N}$ ratio in the soil due to their direct and indirect influence on the mineralization and humification of organic matter. Thanks to earthworms there is a threefold decrease in the $\mathrm{C} / \mathrm{N}$ ratio in the soil as compared to the litter fall (Striganova, 1968). There is experimental evidence of a significant decrease of the $\mathrm{C} / \mathrm{N}$ ratio under the influence of different morpho-ecological groups of earthworms not only in forest soils. For epi-endogeic earthworms, this has been shown in vermicompost (Talashilkar et al., 1999), and for endogeic earthworms - in agricultural fields (Sandor, Schrader 2007; McDaniel et al. 2013).

Earthworms are more often classified as nitroliberants, i.e. soil organisms that have a strong influence on nitrogen migration (Kozlovskaja, 1976; Zhukov et al., 2000), primarily due to the humification of organic matter in the soil. However, earthworms as primary litter decomposers and secondary decomposers of dead plant residues also affect the migration of carbon in soils, so they can also be attributed to the group of carboliberants (mineralizing agents). According to our and literature data, the influence of different morpho-ecological groups of earthworms on the nitrogen content and the $\mathrm{C} / \mathrm{N}$ ratio is similar in the horizons of their activity: the nitrogen content increases, the $\mathrm{C} / \mathrm{N}$ ratio decreases. However, a differential functional approach is required in regard to the effect of earthworms on carbon content. The latest global meta-analysis shows that the presence of not only epigeic and anecic groups, but also of endogeic earthworms leads to a decrease in organic matter in the litter horizon, with the strongest effect being exerted by anecic earthworms (Huang et al., 2020). 


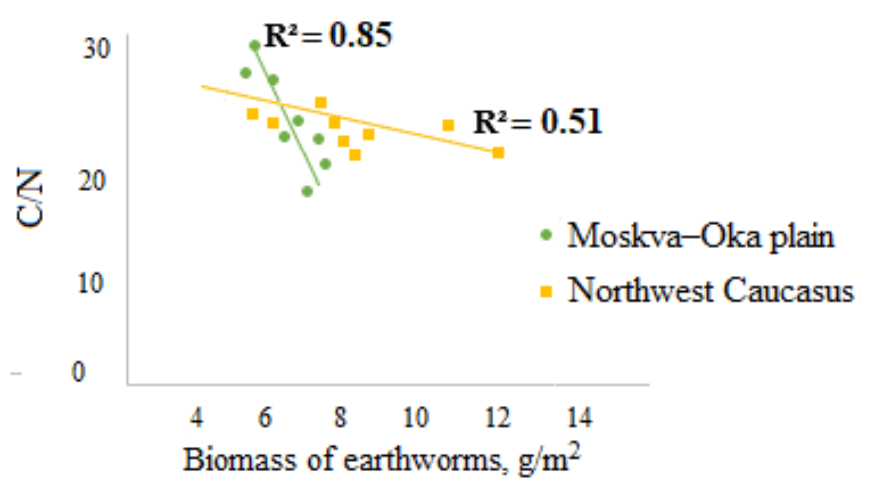

Figure 5. Dependence of the $\mathrm{C} / \mathrm{N}$ ratio in A horizon on the biomass of endogeic earthworms in the forests of the Moskva-Oka plain and the Northwest Caucasus

Our study shows a possible significant negative effect of the group of epi-endogeic earthworms (L. rubellus) on litter store and the content of organic carbon in it. It is known that this species is often confined to rich soils and a high content of organic matter (Zhukov, 2004; Zhukovskaja et al., 2005, etc.). We have identified the relationship between the biomass of the epi-endogeic L. rubellus and increased carbon content in the humus horizon. This is probably due to the high trophic activity of these earthworms and high quality of rapidly decomposing litter fall (birch, linden, hazel). No significant correlations between the biomass of endogeic species and the level of carbon accumulation were revealed, but there is a general trend towards decreased organic carbon content in the humus horizon with an increase in the biomass of this group of species. Endogeic species feed on humus (Perel', 1979; Zhukov, 2004); their coprolites show a decrease in the total mass of organic matter and an increase in ash content by $2-3 \%$ as compared to the soil (Lavelle, Martin, 1992; Angst et al., 2017). Endogeic species are not involved in active movement of litter and transfer of organic carbon to the underlying horizons. To obtain convincing results, more field experiments in forest soils are needed, and we intend to continue our research in this area.

\section{CONCLUSIONS:}

1. With the change in the succession status of forests, the species composition and the set of morpho-ecological groups of earthworms become more complex, but there is no consistent replacement of any one group by others.

2. The species richness, diversity of morpho-ecological groups, and biomass of earthworms with similar granulometric composition of soils is determined by the litter quality: the most favorable type of litter fall for maintaining the functional diversity of earthworms is the mixed litter of broadleaf and coniferous species of the tree canopy, undergrowth, and shrubs.

3. Ambiguous effects of earthworms of different morpho-ecological groups on carbon accumulation in forest soils were revealed. Negative correlations were found between the total biomass of epigeic, epi-endogeic, and anecic earthworm species and the litter carbon content. In the humus horizon, the biomass of epi-endogeic species was positively correlated with the carbon content. This study revealed no relationship between the carbon content of the soil and the earthworm anecic species.

4. Indicators associated with carbon accumulation, i.e. the $\mathrm{C} / \mathrm{N}$ ratio and the nitrogen content, show similar (unidirectional) correlations with the biomass of earthworms in the horizons of their activity: with an increase in the biomass of earthworms of different morpho-ecological groups, the $\mathrm{C} / \mathrm{N}$ ratio decreases, whereas the nitrogen content increases.

\section{ACKNOWLEDGEMENTS}

The research was carried out within the framework of the state assignment CEPF 
RAS No. AAAA-A18-118052590019-7, the material was obtained using the grant of the Russian

\section{REFERENCES}

Abaturov B.D., Pochvoobrazujushhaja rol' zhivotnyh $\mathrm{v}$ biosfere (Soil-forming role of animals in the biosphere), Biosfera $i$ pochvy, Moscow: Nauka, 1976. pp. 53-69.

Alban D.H., Berry E.C., Effects of earthworm invasion on morphology, carbon, and nitrogen of a forest soil, Appl. Soil Ecol., 1994, Vol. 1, pp. 243-249.

Andriuzzi W.S., Schmidt O., Brussaard L., Faber J.H., Bolger T., Earthworm functional traits and interspecific interactions affect plant nitrogen acquisition and primary production, Applied Soil Ecology, 2016, Vol. 104, pp. 148-156.

Angst S., Mueller C.W., Cajthaml T., Angst G., Lhotakova Z., Bartuska M., Spaldonova A., Frouz J., Stabilization of soil organic matter by earthworms is connected with physical protection rather than with chemical changes of organic matter, Geoderma, 2017, Vol. 289, pp. 2935.

Begon M., Harper J.L., Townsend C.R., Ecology: Individuals, Populations and Communities. Oxford: Blackwell Scientifi c Publications, 1986, 1068 p.

Berezina O.G., Struktura naselenija kollembol (Hexapoda, Collembola) reliktovogo lipovogo lesa (Gornaja Shorija, Kemerovskaja oblast') (The spatial structure of springtails community (Hexapoda, Collembola) of the southern forest-steppe of Western Siberia), Evraziatskij jentomologicheskij zhurnal, 2016, Vol. 15, No 6, pp. 583-590.

Bitjuckij N.P., Solov'eva A.N., Lukina E.I., Olejnik A.S., Zavgorodnjaja Ju.A., Demin V.V., Byzov B.A., Jekskrety dozhdevyh chervej stimuljator mineralizacii soedinenij azota $\mathrm{v}$ pochve (Stimulating Effect of Earthworm Excreta on the Mineralization of Nitrogen Compounds in Soil), Pochvovedenie, 2007, No 4, pp. 468-473.

Bohlen P.J., Pelletier D.M., Groffman P.M., Fahey T.J., Fisk M.C., Influence of earthworm invasion on redistribution and retention of soil carbon and nitrogen in
Science Foundation (project No. 16-1710284).

northern temperate forests, Ecosystems, 2004, Vol. 7, pp. 13-27.

Burtelow A.E., Bohlen P.J., Groffman P.M., Influence of exotic earthworm invasion on soil organic matter, microbial biomass and denitrification potential in forest soils of the northeastern United States, Appl. Soil Ecol., 1998, Vol. 9, pp. 197-202.

Curry J.P., Factors affecting the abundance of earthworms in soils. In: Edwards C.A. (Ed.). Earthworm Ecology, 2nd ed., CRC Press, Boca Raton, FL, 1994, pp. 91-113.

Frouz J., Liveckova M., Albrechtoa J., Chronakova A., Cajthaml T., ... \& Simackova H. Is the effect of trees on soil properties mediated by soil fauna? A case study from post-mining sites, Forest Ecology and Management, 2013, Vol. 309, pp. 87-95.

Geras'kina A.P., Preobrazovanija kompleksa dozhdevyh chervej v hode poslerubochnyh sukcescij V lesah Severo-Zapadnogo Kavkaza (Transformations of earthworm communities during post-logging successions in the forests of the Northwest Caucasus), Forest science issues, 2018, No 1, pp. 1-14.

Gilyarov M.S., Metody pochvennozoologicheskih issledovanij (Methods of soil and zoological research), Moscow: Nauka, 1975, $304 \mathrm{p}$.

Gleixner G., Soil organic matter dynamics: a biological perspective derived from the use of compound-specific isotopes studies, Ecological Research, 2013, Vol. 28, No 5, pp. 683-695.

Goncharov A.A., Struktura troficheskih nish v soobshhestvah pochvennyh bespozvonochnyh (mezofauna) lesnyh jekosistem (The structure of trophic niches in the communities of soil invertebrates (mesofauna) of forest ecosystems. Candidate's biol. sci. thesis), Moscow: IPJeJe, 2014, $177 \mathrm{p}$.

Hirth J.R., Li G.D., Chan K.Y., Cullis B.R., Long-term effects of lime on earthworm abundance and biomass in an acidic soil on the south-western slopes of New South 
Wales, Australia, Applied Soil Ecology, 2009, Vol. 43, pp. 106-114.

Hoeffner K., Monard C., Santonja M., Cluzeau D., Feeding behaviour of epianecic earthworm species and their impacts on soil microbial communities, Soil Biology and Biochemistry, 2018, Vol. 125, pp. 1-9.

Holdsworth A.R., Frelich L.E., Reich P.B., Leaf litter disappearance in earthworminvaded northern hardwood forests: role of tree species and the chemistry and diversity of litter, Ecosystems, 2012, Vol. 15, No 6, pp. 913-926.

Huang W., Gonzalez G., Zou X., Earthworm abundance and functional group diversity regulate plant litter decay and soil organic carbon level: A global meta-analysis, Applied Soil Ecology, 2020, Vol. 150, pp. 1-15.

Klassifikacija $i$ diagnostika pochv Rossii (Classification and diagnostics of Russian soils), Shishov L.L., Tonkonogov V.D., Lebedeva I.I., Gerasimova M.I. (Compl.), Smolensk: Ojkumena, 2004, 342 p.

Kozlovskaja L.S., Archegova I.B., Rakova H.N., Biohimicheskoe vozdejstvie pochvennyh bespozvonochnyh na rastitel'nye ostatki (Biochemical effects of soil invertebrates on plant debris), Bolotnye biogeocenozy $i$ ih izmenenija $v$ rezul'tate antropogennogo vozdejstvija, Leningrad: Nauka, 1983, pp. 24-26.

Kozlovskaja L.S., Rol' pochvennyh bespozvonochnyh $v \quad$ transformacii organicheskogo veshhestva bolotnyh pochv (The role of soil invertebrates in the transformation of organic matter of bog soils), Leningrad, 1976, $211 \mathrm{p}$.

Kuznecova A.I., Lukina N.V., Tihonova E.V., Gornov A.V., Gornova M.V., Smirnov V.E., Geras'kina A.P., Shevchenko N.E., Teben'kova D.N., Chumachenko S.I., Akkumulyaciya ugleroda $\mathrm{v}$ peschanyh i suglinistyh pochvah ravninnyh hvojnoshirokolistvennyh lesov $\mathrm{v}$ hode poslerubochnyh vosstanovitel'nyh sukcessij (Carbon stock in sandy and loamy soil of coniferous-deciduous forestsat the different stages of successions), Pochvovedenie, 2019, No 7, pp. 803-816.
Lavelle P., Martin A., Small-scale and largescale effects of endogeic earthworms on soil organic matter dynamics in soils of the humid tropics, Soil Biology and Biochemistry, 1992, Vol. 24, No. 12, pp. 1491-1498.

Lavelle P., Pashanasi B., Charpentier F., Gilot C., Rossi J.-P., ...\& Bernier N., Largescale effects of earthworms on soil oranic matter and nutrient dynamics, Edwards C.A. (Ed.), Earthworm ecology, St. Lucie Press, 1998, pp.103-122.

Lee K.E., Earthworms. Their ecology and relationships with soils and land use, Academic Press, 1985, 411 p.

Lukina N.V., Tihonova E.V., Shevchenko N.E., Gornov A.V., Kuznecova A.I., .. \& \& Shanin V.N., Akkumuljacija ugleroda $v$ lesnyh pochvah i sukcessionnyj status lesov (Carbon accumulation in forest soils and forest succession status), N.V. Lukina (Ed.), Moscow: KMK, 2018, 232 p.

Makeschin F., Earthworms (Lumbricidae: Oligochaeta): Important promoters of soil development and soil fertility, G. Benckiser (Ed.), Fauna in soil ecosystems. Recycling processes, nutrient fluxes and agricultural production, Florida: CRC Press, 1997, pp. 173-223.

McDaniel J.P., Stromberger M.E., Barbarick K.A., Cranshaw W., Survival of Aporrectodea caliginosa and its effects on nutrient availability in biosolids amended soil, Applied soil ecology, 2013, Vol. 71, pp. 1-6.

Mengel K., Turnover of organic nitrogen in soils and its availability to crops, Plant and Soil, 1996, Vol. 181, pp. 83-96.

Metodicheskie ukazanija po kolichestvennomu opredeleniju obema pogloshhenija parnikovyh gazov (Guidelines for the quantification of greenhouse gas absorption), Rasporjazhenie Minprirody Rossii 30.06.2017, No 20-r, 108 p.

Moore J.-D., Ouimet R., Bohlen P.J., Effects of liming on survival and reproduction of two potentially invasive earthworm species in nothern forest Podzol, Soil Biology and Biochemistry, 2013, Vol. 64, pp. 174-180.

Nacional'nyj atlas pochv Rossijskoj Federacii (National Atlas of Soils of the Russian Federation), Shoba S.A., Aljabina I.O., 
Urusevskaja I.S., Chernova O.V., Moskow: Astrel', 2011, 632 p.

Novara A., Rühl J., La Mantia, T., Gristina L., La Bella, S., Tuttolomondo T., Litter contribution to soil organic carbon in the processes of agriculture abandon, Solid Earth, 2015, Vol. 6, No 2, pp. 425-432.

Parmelee R.W., Crossley Jr., Earthworm production and role in the nitrogen cycle of a no-tillage agroecosystem on the Georgia piedmont, Pedobiologia, 1988, Vol. 32, pp. 353-361.

Perel' T.S., Rasprostranenie i zakonomernosti raspredelenija dozhdevyh chervej fauny SSSR (Distribution and distribution patterns of earthworms of the fauna of the USSR), Moskow: Nauka, 1979, 272 .

Pulleman M.M., Six J., Uyl A., Marinissen J.C.Y., Jongmans A.G., Earthworms and management affect organic matter incorporation and microaggregate formation in agricultural soils, Appl. Soil Ecol., 2005, Vol. 29, pp. 1-15.

Sandor M., Schrader S., Earthworms affect mineralization of different organic amendments in a microcosm study, Bulletin of University of Agricultural Sciences and Veterinary Medicine ClujNapoca. Agriculture, 2007, Vol. 63, pp. 442-447.

Sariyildiz T., Effects of tree canopy on litter decomposition rates of Abies nordmanniana, Picea orientalis and Pinus sylvestris, Scandinavian journal of forest research, 2008, Vol. 23, No. 4, pp. 330338.

Sariyildiz T., Küçük M., Litter mass loss rates in deciduous and coniferous trees in Artvin, northeast Turkey: Relationships with litter quality, microclimate, and soil characteristics, Turkish journal of Agriculture and Forestry, 2008, Vol. 32, No. 6, pp. 547-559.

Shevchenko N.E., Kuznecova A.I., Teben'kova D.N., Smirnov V.E., Geras'kina A.P., Gornov A.V., Tihonova E.V., Lukina N.V., Sukcessionnaya dinamika rastitel'nosti i zapasy pochvennogo ugleroda $\mathrm{v}$ hvojno-shirokolistvennyh lesah severo-zapadnogo Kavkaza (The succession dynamics of vegetation and carbon stocks in coniferous-deciduous forests of the north-western Caucasus), Lesovedenie, 2019, No 3, pp. 163-176.

Striganova B.R., Issledovanie roli mokric i dozhdevyh chervej $\mathrm{v}$ processah gumifikacii razlagajushhejsja drevesiny (Investigation of the role of woodlice and earthworms in the processes of humification of decaying wood), Pochvovedenie, 1968, №. 8, pp. 8590.

Striganova B.R., Kozlovskaja L.S., Chernobrovkina N.P., Kudrjasheva I.V., Pishhevaja aktivnost' dozhdevyh chervej i soderzhanie aminokislot $\mathrm{V}$ temnoseroj lesnoj pochve (Alimentative activity of earthworms and content of aminoacids in the dark grey forest soil), Pochvovedenie, 1989, No 5, pp. 44-51.

Striganova B.R., Pitanie pochvennyh saprofagov (Nutrition of soil saprophages), Moskow: Nauka, 1980, 243 p.

Striganova B.R., Sukcessii zhivotnogo naselenija pochvy $\mathrm{v}$ processe pervichnogo pochvoobrazovanija (Successions of the animal population of the soil in the process of primary soil formation), Rannjaja kolonizacija sushi, Moskow: PIN RAN, 2012, pp. 177-195.

Suarez E.R., Fahey T.J., Yavitt J.B., Groffman P.M., Bohlen P.J., Patterns of litter disappearance in a northern hardwood forest invaded by exotic earthworms, Ecological Applications, 2006, Vol. 16, No 1, pp. 154-165.

Talashilkar S.C., Bhangarath P.P., Mehta V.B., Changes in chemical properties during composting of organic residues as influenced by earthworm activity, Journal of the Indian Society of Soil Science, 1999, Vol. 47, pp. 50-53.

Vsevolodova-Perel' T.S., Dozhdevye chervi fauny Rossii. Kadastr i opredelitel' (Earthworms of Russia. Cadastr and keybook.), Moskow: Nauka, 1997, 101 p.

Vsevolodova-Perel' T.S., Gryuntal' S.Yu., Kudryasheva I.V., Nadtochij S.E., Golovach S.I., Matveeva A.A., Osipov V.V., Karpachevskij L.O., Rastvorova O.G., Struktura $i$ funkcionirovanie pochvennogo naseleniya dubrav Srednerusskoj lesostepi (The structure and functioning of the soil population of the 
oak forests of the Central Russian foreststeppe). Moscow: Nauka, 1995, 152 p.

World Reference Base for Soil Resources, International soil classification system for naming soils and creating legends for soil maps. World Soil Resources Reports, IUSS Working Group. Rome: FAO, 2015, 203 p.

Zhukov A.V., Dozhdevye chervi kak komponent biogeocenoza i ih rol' $\mathrm{v}$ zooindikacii (Earthworms as a component of biogeocenosis and their role in zooindication), Iruntoznavstvo, 2004, Vol. 5, No 1-2, pp. 44-57.

Zhukov A.V., Jekologicheskoe raznoobrazie zhivotnogo naselenija pochv pojmennyh biogeocenozov reki Samara (Ecological diversity of the animal population in the soils of floodplain biogeocenoses of the Samara River), Visnik Dnipropetrovs'kogo universitetu. Biologija. Ekologija, 2000, No 7. pp. 73-79.

Zhukovskaja E.A., Kodolova O.P., Pravduhina O.Ju., Varne A.Zh., Boloteckij N.M., Issledovanie geneticheskogo raznoobrazija dozhdevogo chervja Lumbricus rubellus Hoff. (Oligochaeta, Lumbricidae) (Study of genetic diversity of earthworm Lumbricus rubellus Hoff. (Oligochaeta, Lumbricidae), Izvestija Rossijskoj akademii nauk. Serija biologicheskaja, 2005. No 5. pp. 625-627.

Reviewer: candidate of Biological Sciences, Senior Research Officer Zenkova I.V. 